\begin{tabular}{|ll|}
\hline Received & $:$ 2 January 2019 \\
Revised & $: 13$ February 2019 \\
Accepted & $:$ 26 March 2019 \\
Published & $:$ 30 June 2019 \\
\hline
\end{tabular}

\title{
Developing Syllabus and Reading Teaching Materials for BIPA A1 Based on Deductive Approach
}

\author{
Siti Ayu Ningsih ${ }^{1, a)}$, Liliana Muliastuti ${ }^{1, b)}$ \\ Universitas Negeri Jakarta, Jakarta, Indonesia \\ E-mail: ${ }^{\text {a) }}$ sitiayuningsih_pb16s2@mahasiswa.unj.ac.id, ${ }^{\text {b) }}$ liliana.muliastuti@unj.ac.id
}

\begin{abstract}
This study aims to describe: 1) the development of reading syllabus for BIPA level A1 using deductive approach in D'Royal Moroco Integrative Islamic Elementary School, and 2) the development of reading teaching material for BIPA level A1 using deductive approach in D'Royal Moroco Integrative Islamic Elementary School. The method used in this research was research and development method. Based on the observations, documents analysis, interviews, and tests, during need analysis period, can be elaborated that the school did not have any teaching materials for BIPA. While the school had quite a lot of BIPA students mostly at A1 level. This situasions need immediate action of developing syllabus and reading teaching material for BIPA at A1 level. Due to the target of the users for this syllabus and teaching material, deductive approach can be used to developing the syllabus and the reading teaching material of BIPA A1 since the children learn more effectively by imitating the examples, and deductive approach suits that needs. By following the deductive approach, the syllabus should contains the role of teacher and students while the teaching material should have: 1) begins with the concept introduction, 2) followed by relevant examples, and 3) contains of adequate practice. It is also should containing relevant and interesting illustrations.
\end{abstract}

Keywords: developing, syllabus, teaching material, BIPA A1 reading, deductive

\begin{abstract}
Abstrak
Penelitian ini bertujuan untuk mendeskripsikan: 1) penyusunan silabus membaca bagi siswa BIPA (Bahasa Indonesia Penutur Asing) tingkat A1 dengan pendekatan deduktif di Sekolah Dasar D'Royal Moroco Integrative Islamic School, dan 2) penyusunan materi ajar membaca bagi siswa BIPA (Bahasa Indonesia Penutur Asing) tingkat A1 dengan pendekatan deduktif di Sekolah Dasar D'Royal Moroco Integrative Islamic School. Metode penelitian yang digunakan merupakan penelitian pengembangan. Berdasarkan hasil observasi, analisis dokumen, wawancara, dan tes dalam tahap eksplorasi analisis kebutuhan, dapat dijabarkan bahwa sekolah tersebut belum memiliki silabus dan materi ajar khusus bagi para siswa BIPA, sedangkan di sekolah tersebut
\end{abstract}


memiliki cukup banyak siswa BIPA khususnya tingkat A1. Hal ini menjadikan pentingnya silabus dan materi ajar membaca BIPA tingkat A1 untuk segera dikembangkan. Pendekatan deduktif dapat digunakan untuk mengembangkan silabus dan materi ajar membaca BIPA A1 karena anak-anak belajar lebih efektif dengan menirukan contoh sebagaimana ciri dari pendekatan deduktif yang sesuai dengan kebutuhan tersebut. Berbasis pada pendekatan deduktif, silabus harus memuat peran guru dan siswa sebagaimana ciri deduktif yakni berpusat pada guru. Adapun komponenkomponen lain dalam silabus tetap dipertahankan. Dalam materi ajar harus memiliki: 1) dimulai dengan pengenalan konsep, 2) diikuti oleh contoh yang relevan, dan 3) berisi praktik yang memadai. Dalam kaitannya dengan penggunaan materi bagi siswa SD yang masih tergolong anak-anak, maka materi ajar yang dikembangkan juga harus memuat ilustrasi yang menarik.

Kata kunci: penyusunan, silabus, materi ajar, membaca BIPA A1,deduktif

\section{PENDAHULUAN}

Bahasa Indonesia merupakan mata pelajaran wajib untuk diajarkan di sekolah formal sebagaimana dimandatkan dalam Undang-undang Nomor 24 Tahun 2009 tentang Bendera, Bahasa, dan Lambang Negara, serta Lagu Kebangsaan. Keberadaannya di sekolah tidak sebatas pada sekolah nasional berstatus negeri maupun swasta. Sekolah berstatus internasional yang berubah nama menjadi Satuan Pendidikan Kerjasama atau yang disingkat menjadi SPK juga diwajibkan untuk mengajarkan bidang studi Bahasa Indonesia sebagaimana tertuang dalam Peraturan Menteri Pendidikan dan Kebudayaan Republik Indonesia Nomor 31 Tahun 2014 tentang kerja sama penyelenggaraan dan pengelolaan pendidikan oleh lembaga pendidikan asing dengan lembaga pendidikan di Indonesia.

Dalam kaitannya dengan pemberlakuan Peraturan Menteri tersebut, setiap siswa yang bersekolah di SPK akan mempelajari bahasa Indonesia. Perbedaannya terletak pada status wajib atau pilihan yang dipengaruhi oleh kewarganegaraan siswa yang bersekolah di sekolah tersebut. Siswa berkewarganegaraan Indonesia wajib mengikuti bidang studi Bahasa Indonesia sedangkan siswa asing dapat memilih untuk mengikuti atau pun tidak mengikuti.

Sebagai penutur asing yang mempelajari bahasa Indonesia di Indonesia, seharusnya siswa asing mendapatkan kelebihan berdasarkan pendapat yang menyatakan bahwa pembelajaran bahasa asing yang ideal terjadi apabila proses belajar bahasa itu dilakukan dalam suatu budaya, negara, atau tempat bahasa itu digunakan. Kontak langsung dengan masyarakat penutur bahasa asli serta hal-hal yang berkaitan dengan bahasa tersebut akan membuat bahasa tersebut mudah dipahami (Rivai, 2010); (Suhartatik, 2018). Inilah faktor pendukung yang penting dalam keberhasilan belajar suatu bahasa. Hal tersebut diperkuat oleh pendapat yang menyatakan bahwa cara yang baik dalam mempelajari bahasa kedua yaitu dengan terlibat dalam konteks dan komunikasi yang bermakna, yaitu praktik secara langsung (Brown, 1995).

Berdasarkan pendapat tersebut, seharusnya siswa BIPA di SD D'Royal Moroco Integrative Islamic School mendapatkan keuntungan sebagaimana dipaparkan Rivai. Akan tetapi, faktanya tidak sesederhana anggapan tersebut. Masalah muncul ketika 
siswa BIPA di SD D'Royal Moroco Integrative Islamic School keadaannya sangat dinamis. Tidak semua siswa BIPA berada di kelas rendah seperti kelas 1 atau kelas 2 . Mereka tersebar di semua kelas karena tahun masuk para siswa BIPA ke sekolah tersebut tidak selalu sama karena terkait erat dengan masa kedatangan mereka ke Indonesia. Masalah lainnya adalah siswa BIPA mendapatkan pengajaran Bahasa Indonesia dengan standar yang sama dengan siswa non-BIPA. Mereka ditempatkan dalam kelas yang sama dengan kurikulum, materi ajar, sumber belajar, dan proses evaluasi yang sama saat proses pengajaran bahasa Indonesia berlangsung.

Siswa BIPA dan non-BIPA tentu saja memiliki karakteristik yang berbeda dalam mempelajari bahasa Indonesia. Siswa non-BIPA umumnya telah mengetahui konsep bahasa Indonesia sedangkan siswa BIPA yang merupakan penutur bahasa asing hanya mengetahui konsep-konsep bahasa ibunya (Muliastuti, 2017). Dengan demikian, jika terdapat perbedaan konsep antara bahasa ibunya dan bahasa Indonesia yang sedang dipelajarinya, diperlukan suatu materi ajar yang tepat untuk membantu mereka agar terampil berbahasa Indonesia.

Perbedaan pengetahuan konsep bahasa antara penutur asli bahasa Indonesia dan penutur asing membuat standar kompetensi yang harus dicapai keduanya juga menjadi berbeda. Pemerintah telah menetapkan standar kompetensi lulusan untuk pengajaran Bahasa Indonesia bagi penutur asing dalam Permendikbud Nomor 27 Tahun 2017 (Kementerian Pendidikan dan Kebudayaan, 2017). Peraturan tersebut membagi level kompetensi dalam 7 tingkat. Adapun siswa SD dapat mengikuti BIPA tingkat 1 sampai dengan tingkat 2. Untuk tingkat 1 ini sama dengan tingkat A1 dalam CEFR atau Common European Framework of Reference for Language (Council of Europe, 2001). CEFR sendiri menjadi salah satu acuan standardisasi Permendikbud yang dimaksud. Acuan lainnya yaitu UKBI yang merupakan singkatan dari Uji Kemahiran Bahasa Indonesia.

Dalam setiap tingkatan BIPA, diajarkan empat keterampilan berbahasa. Empat keterampilan tersebut memiliki proses yang saling terkait dan berurutan mulai dari menyimak, berbicara, membaca, dan menulis. Keterampilan membaca merupakan salah satu keterampilan yang sangat penting untuk dikembangkan karena membaca merupakan kunci gudang ilmu (Tarigan, 1986; Purwahida, 2017). Posisi keterampilan membaca ini menurut menduduki posisi vital dalam keberhasilan suatu pencapaian hasil belajar sehingga perlu mendapat perhatian khusus (Sudiana, 2007). Penelitian terkait dengan membaca pernah dilakukan oleh beberapa peneliti sebelumnya (Khusniyah \& Lustyantie, 2017; Santosa, Rafli, \& Lustyantie, 2018; Biduri, Rasyid, \& Emzir, 2018).

Siswa BIPA kelas paling rendah disebut dengan tingkat A1. Siswa pada tingkat ini memiliki kemampuan berbahasa Indonesia yang masih pada tingkat nol. Oleh karena itu, perlu dirancang pembelajaran membaca secara khusus. Membaca merupakan keterampilan yang harus dikuasai pertama sebelum mempelajari keterampilan aktif produktif. Selain itu, posisi membaca sebagai tahap permulaan sangat vital dalam kaitannya dengan pengajaran bahasa kedua pada tahap awal.

Dalam kaitannya dengan pembelajaran bahasa kedua, terdapat tantangan tersendiri dalam penggunaan bahasa target sebagai bahasa pengantar sehingga sedikit atau banyak guru masih memerlukan bantuan dari bahasa pertama siswa untuk dapat menyampaikan materi ajar. Dalam pendekatan deduktif, penggunaan bahasa target masih harus dibatasi karena agak sulit menggunakan bahasa target. Oleh karena itu, pembelajaran masih perlu dibantu dengan bahasa pertama siswa. Selain itu, terdapat ketidakteraturan dalam berlatih menerjemahkan kalimat dari bahasa target ke bahasa ibu siswa. Pernyataan 
tersebut merupakan kutipan dari hasil penelitianberjudul The Effect of Using Inductive and Deductive Methods on $7^{\text {th }}$ Grade Students Achievement in Grammar in Bethlehem District and their Attitude toward EFL (Hmedan \& Nafi, 2016).

Dengan berlandaskan pada pendapat tersebut, maka jelaslah meski dalam konteks pengajaran BIPA di mana bahasa Indonesia menjadi bahasa target, penggunaannya tidak dapat diberikan secara bertubi dan tiba-tiba dalam jumlah yang signifikan karena dapat memberikan efek kejut pada siswa. Mengingat siswa SD masuk dalam kategori anak-anak, maka penguasaan bahasa kedua anak-anak berproses jauh lebih mudah melalui peniruan (Riley, 2006; Purwahida, 2018). Dengan demikian, pendekatan deduktif dapat menjawab tantangan-tantangan tersebut. Dengan demikian, analisis kebutuhan yang dilakukan ini dispesifikkan pada analisis kebutuhan materi ajar membaca BIPA A1 dengan pendekatan deduktif.

Pendekatan deduktif merupakan proses penalaran yang bermula dari keadaan umum ke khusus. Sebagai pendekatan pengajaran, bermula dari menyajikan aturan, prinsip umum yang disertai contoh-contoh khusus atau penerapan aturan. Lebih lanjut, langkah-langkah dalam menuangkan pendekatan deduktif ke dalam materi ajar dapat menempuh langkah-langkah berikut, (1) memilih konsep, prinsip, aturan yang akan disajikan, (2) menyajikan konsep, prinsip, dan aturan yang bersifat umum lengkap dengan definisinya, (3) menyajikan contoh-contoh khusus yang sesuai dengan konsep yang telah dipaparkan, dan (4) menyajikan bukti-bukti yang menunjang (Sagala, 2008). Ditambahkan pula bahwa pendekatan deduktif terkait dengan pewaktuan dan latihan yang berkaitan dengan topik di mana siswa terlebih dahulu diberi penjelasan (Shaffer, 1989). Penelitian terkait materi ajar BIPA dengan menggunakan analisis kebutuhan sebagai langkah awal yang dilanjutkan dengan penyusunan silabus juga pernah dilakukan (Muliastuti, 2014); (Purwahida, 2017).

Silabus didefinisikan sebagai panduan bagi guru dan siswa dalam upaya mencapai tujuan pembelajaran (Brown, 1995). Bagi guru, silabus memberikan panduan seputar cakupan pembelajaran. Bagi siswa, silabus memberikan gambaran umum materi dan tugas-tugas yang akan dilakukan dalam program pembelajaran. Di samping itu, silabus harus berkaitan dengan kurikulum yang berlaku (Brumfit, 1984). Silabus dijadikan sebagai acuan dalam menyusun materi ajar.

Materi ajar merupakan sumber belajar yang terdeskripsi secara sistematis dari teknik-teknik serta latihan-latihan yang akan digunakan dalam kegiatan pembelajaran dan mencakup rencana pengajaran yang digunakan guru untuk bahan pembelajaran yang dikembangkan dengan mengacu pada program dalam silabus yang dalam membelajarkannya disesuaikan dengan kebutuhan dan lingkungan peserta didik (Brown, 1995); (Agustina, R. \& Hariyadi, 2018). Sumber belajar tersebut dapat berbentuk bahan cetak, kinerja ataupun contoh model, kaset, CD-ROM, DVD, atau internet, permainan, atau kegiatan lainnya yang terjadi di dalam kelas sehingga dapat mengakomodasi siswa visual, audio, audiovisual, dan kinestetik (Tomlinson, 2007).

Berdasarkan paparan masalah dan penelitian-penelitian yang sudah ada tersebut, perlu dilakukan sebuah penelitian yang berkaitan dengan penyusunan silabus dan materi ajar membaca bagi siswa BIPA A1 dengan menggunakan pendekatan dedukif di D'Royal Moroco Integrative Islamic School sebagai bagian dari rangkaian pengembangan. 


\section{METODE PENELITIAN}

Metode penelitian pengembangan terdiri atas 10 langkah yang meliputi (1) studi pendahuluan melalui analisis kebutuhan, (2) penyusunan rencana penelitian, (3) penyusunan produk yang akan dikembangkan, (4) uji kepakaran, (5) revisi produk, (6) uji kelompok kecil, (7) revisi produk, (8) uji kelompok besar, (9) revisi produk, serta (10) diseminasi dan implementasi produk (Borg, Gall, \& Gall, 2003). Adapun penelitian ini merupakan bagian dari penelitian pengembangan yang berada pada tahap kedua dan ketiga dalam rangkaian penelitian pengembangan Borg, Gall, dan Gall secara keseluruhan yakni, tahap perencanaan dan penyusunan silabus serta materi ajar sebagai produk pengembangan. Tahap tersebut dilakukan setelah diperoleh data hasil analisis kebutuhan dan situasi dari tahapan sebelumnya.

\section{HASIL DAN PEMBAHASAN}

Hasil penelitian ini diuraikan berdasarkan dua aspek, yaitu (1) deskripsi silabus membaca BIPA A1 berbasis pendekatan deduktif, dan (2) deskripsi materi ajar membaca BIPA A1 berbasis pendekatan deduktif.

\section{Deskripsi Silabus Membaca BIPA A1 Berbasis Pendekatan Deduktif}

Silabus membaca BIPA A1 berbasis pendekatan deduktif disusun dengan mengacu pada pendapat para ahli mengenai silabus yang telah disintesiskan sehingga akhirnya silabus tersebut terdiri atas komponen-komponen sebagai berikut, (1) alokasi waktu, (2) standar kompetensi, (3) kompetensi dasar, (4) indikator, (5) judul unit yang dipelajari, (6) materi pokok yang di dalamnya memuat materi utama yang berkaitan dengan judul unit yang disertai materi kebahasaan dan juga wawasan budaya Indonesia, (7) kegiatan pembelajaran, dan (8) evaluasi.

Alokasi waktu mengacu pada kalender akademik sebagai bagian dari program tahunan dan program semester di SD D'Royal Moroco Integrative Islamic School. Standar kompetensi dan kompetensi dasar mengacu pada Permendikbud Nomor 27 tahun 2017 sebagai kurikulum acuan bagi pengajaran BIPA. Adapun indikator disusun dengan mengacu pada kompetensi dasar yang ada. Selanjutnya, judul unit yang menjadi tema setiap unitnya diperoleh dari hasil analisis kebutuhan dan situasi. Unitnya berjumlah delapan ditambah satu unit tambahan sebagai prapengajaran yang berisikan materi tentang suku kata dan huruf serta cara membaca angka. Pengurutan delapan tema dimulai dari tema-tema yang terdekat dengan siswa terlebih dahulu. Pengejawantahan tema sebagai judul unit tertuang dalam bentuk materi utama yang disegmentasikan dalam membaca kosakata, kalimat, dan wacana. Adapun tata bahasa yang dipelajari pada setiap unit mengacu pada kurikulum yang sama dengan mempertimbangkan tingkat kesulitan. Materi tata bahasa yang disisipkan dalam kolom materi pokok digradasikan dari yang termudah hingga yang tersulit. Adapun sisipan wawasan budaya Indonesia merupakan konsekuensi dari mandat Permendikbud Nomor 31 Tahun 2014 tentang kerja sama penyelenggaraan dan pengelolaan pendidikan oleh lembaga pendidikan asing dengan lembaga pendidikan di Indonesia. Tercantum bahwa pengajaran bahasa Indonesia sebagai bahasa asing juga perlu disertai dengan pengajaran budaya Indonesia. Keberadaan informasi seputar budaya Indonesia ini tidak dikemas dalam unit khusus karena mengacu pada hasil analisis kebutuhan yang telah dilakukan. 
Selanjutnya, pendekatan deduktif memiliki pola umum-khusus yang menjadi ciri khasnya. Pola umum-khusus artinya dimulai dari konsep teoretis, diikuti dengan bentuk realitas atau penyajian contoh dari aturan yang terdapat dalam konsep awal. Dengan demikian, dalam kaitannya dengan contoh, peran guru sangatlah besar dalam pendekatan ini sehingga dapat juga dinyatakan bahwa pendekatan ini berpusat pada guru. Sehubungan dengan hal tesebut, peran guru dan siswa dijabarkan dalam silabus pada bagian kegiatan pembelajaran. Guru memiliki peran besar dalam memberikan contoh berkaitan dengan kegiatan membaca dan siswa dapat menirukan contoh yang diberikan sebelum berlatih mandiri dan melanjutkan ke proses evaluasi.

Evaluasi membaca yang dicantumkan dalam silabus memiliki dua jenis, yakni evaluasi membaca lisan dan evaluasi membaca nonlisan. Evaluasi lisan dilakukan langsung oleh guru, sedangkan eveluasi nonlisan berkaitan dengan kegiatan menjawab secara nonlisan atau menjawab secara tertulis pertanyaan-pertanyaan yang berkaitan dengan materi yang dipelajari. Kegiatan tersebut berkaitan erat dengan pemahaman siswa terhadap bacaan.

\section{Deskripsi Materi Ajar Membaca BIPA A1 Berbasis Pendekatan Deduktif}

Berdasarkan silabus yang telah dikembangkan, maka penyusunan materi ajar mengacu pada silabus tersebut. Materi ajar yang disusun berupa buku teks pelajaran yang terdiri atas buku siswa dan buku guru. Pada buku siswa, dimulai dengan halaman kata pengantar, daftar isi, dilanjutkan dengan bab khusus prapengajaran dan bab-bab lainnya sesuai judul unit sebagai tema dalam menyajikan materi, lalu ditutup dengan daftar pustaka.

Bab prapengajaran memuat materi membaca yang dimulai dari pelafalan suku kata. Setelah suku kata, dilanjutkan dengan pengenalan huruf dan angka. Ciri dari membaca permulaan secara deduktif yang tidak dimulai dari huruf. Pengajarannya dapat dimulai dari suku kata, kata, kalimat, bahkan wacana namun tidak terikat harus memulai dari mana, yang terpenting tidak mulai dari huruf (Wahyuni, 2013).

Selanjutnya, berdasarkan topik-topik yang telah dipilih para pengajar dan siswa berikut dijabarkan muatan-muatan materi yang terdapat dalam topik-topik tersebut.

\section{BAB I PERKENALAN}

1. Membaca nyaring nama-nama orang dengan cara melafalkan

2. Membaca nyaring nama-nama negara dengan cara melafalkan

3. Membaca nyaring nama-nama anggota tubuh dengan cara melafalkan

4. Kebahasaan: Pronomina dan kata tanya (siapa, apa, dan apakah)

5. Membaca lancar kalimat perkenalan diri

6. Membaca lancar kalimat memperkenalkan orang lain

7. Wawasan tentang Indonesia (sikap berkenalan orang Indonesia)

8. Latihan Bab 1

\section{BAB II SEKOLAHKU}

1. Membaca nyaring nama-nama benda di dalam kelas

2. Membaca nyaring nama-nama warna

3. Kebahasaan : kata ganti penunjuk dan frasa benda

4. Membaca nyaring nama-nama bidang studi dan nama-nama hari

5. Membaca memindai jadwal pelajaran 
6. Kebahasaan : kalimat sederhana berpola S-P-Pel

7. Wawasan tentang Indonesia (seragam sekolah di Indonesia)

8. Latihan Bab 2

\section{BAB III RUMAH DAN KELUARGAKU}

1. Membaca nyaring silsilah anggota keluarga

2. Membaca nyaring kata-kata kerja yang berkaitan dengan kegiatan sehari-hari

3. Kebahasaan (imbuhan me- )

4. Membaca denah lokasi

5. Kebahasaan (kata ganti penunjuk arah, kata tanya bagaimana, kata depan di, ke, dan dari)

6. Wawasan tentang Indonesia (rumah adat di Indonesia)

7. Latihan Bab 3

\section{BAB IV TEMPAT UMUM}

1. Membaca nyaring nama-nama tempat umum

2. Kebahasaan (penggunaan angka, kata tanya berapa)

3. Membaca nominal mata uang rupiah

4. Membaca memindai brosur iklan

5. Membaca memindai teks pengumuman

6. Kebahasaan (ungkapan dasar sehari-hari)

7. Membaca lancar teks percakapan

8. Wawasan tentang Indonesia (pedagang kaki lima)

9. Latihan Bab 4

\section{BAB V TRANSPORTASI}

1. Membaca nyaring nama-nama alat transportasi

2. Kebahasaan (kata negasi bukan dan tidak, kata posisi dan lokasi, kata kerja ada)

3. Membaca dangkal teks deskripsi

4. Wawasan tentang Indonesia (alat transportasi tradisional getek)

5. Latihan Bab 5

\section{BAB VI ULANG TAHUN}

1. Membaca memindai kartu undangan pesta ulang tahun

2. Kebahasaan (kata tanya kapan dan di mana, kata ganti kepemilikan, kata bilangan tingkat)

3. Membaca memindai kartu ucapan ulang tahun

4. Kebahasaan (kosakata sapaan khusus dalam surat pribadi, kosakata untuk mengungkapan selamat)

5. Wawasan tentang Indonesia (Tradisi lompat batu di Nias pertanda kedewasaan)

6. Latihan Bab 6

\section{BAB VII HOBI}

1. Membaca nyaring ragam hobi

2. Kebahasaan (kalimat sederhana berpola S-P-O)

3. Membaca narasi

4. Wawasan tentang Indonesia (permainan tradisional Engklek)

5. Latihan Bab 7 


\section{BAB VIII REKREASI}

1. Membaca nyaring nama-nama tempat berlibur

2. Kebahasaan (konjungsi, ajektiva, imbuhan -an, kalimat berpola S-P-O dan S-P$\mathrm{O}-\mathrm{K})$

3. Membaca pemahaman teks narasi

4. Wawasan tentang Indonesia (budaya oleh-oleh)

5. Latihan Bab 8

Dalam kegiatan membaca bagi BIPA A1, penyusunan materi ajar dapat dimulai dari hal-hal yang bersifat pribadi seputar diri sendiri, seperti tentang identitas diri, baik dalam biodata maupun konteks interaksi perkenalan. Penekanan dalam topik identitas ini terletak pada pengajaran pelafalan dalam kaitannya dengan membaca nyaring di samping mengidentifikasi identitas diri.

Selanjutnya, siswa mulai diperkenalkan dengan kosakata-kosakata yang berkaitan dengan tema. Setiap kosakata disertai ilustrasi yang berkaitan dengan kosakata tersebut, dilanjutkan dengan pengajaran teks-teks sederhana yang sangat dekat dengan keseharian mereka baik itu di sekolah maupun di rumah. Namun, teks yang didahulukan merupakan teks yang ada di sekolah karena dapat langsung dikonkretkan contohnya dan disajikan di hadapan pemelajar secara langsung. Teks-teks yang dimaksud antara lain jadwal pelajaran sekolah, denah lokasi, brosur iklan, pengumuman, dan deskripsi serta narasi singkat dan sederhana yang tersebar dalam bab-bab lainnya. Begitu juga dengan pengajaran tata bahasa dan budaya Indonesia yang tersebar di setiap babnya.

Adapun buku guru dimulai dengan halaman kata pengantar, petunjuk umum, daftar isi, dan unit-unit sebagaimana yang terdapat dalam buku siswa. Hanya saja, dalam setiap unit dimuat langkah-langkah pengajaran secara konkret sebagai wujud dari petunjuk khusus yang dapat membantu guru dalam melaksanakan pengajaran di kelas. Diharapkan dalam pengajaran membaca juga dapat menstimulasi keterampilan berbahasa yang lainnya seperti menyimak, menulis, dan berbicara. Keterampilan menyimak distimulasi dalam kegiatan awal, yakni saat melafalkan setiap kosakata yang akan dipelajari dalam setiap bab. Kegiatan menulis distimulasi dengan latihan memahami bacaan, adapun kegiatan berbicara dapat distimulasi dengan diskusi mengenai budaya Indonesia. Selain petunjuk khusus, terdapat juga kunci jawaban untuk setiap latihan dalam buku. Kunci jawaban tersebut tidak tercantum dalam buku siswa namun tercantum dalam buku guru. Perlu ditekankan, bahwa keberadaan buku guru ini sifatnya untuk membantu guru dalam menggunakan buku teks dalam pengajaran, bukan merupakan aturan mutlak yang harus diikuti.

Pada akhirnya, keberadaan suatu materi ajar menjadi sangat penting dalam kaitannya dengan mendukung keberlangsungan suatu proses pembelajaran. Membaca dalam konteks pengajaran suatu bahasa sebagai suatu bahasa asing di tingkat pemula, disepakati dalam studi pendahuluan sebagai keterampilan pertama yang perlu dikuasai sebelum merambah ke keterampilan lainnya. Pendekatan deduktif disepakati oleh sebagian besar pengajar sebagai pendekatan yang sesuai dengan situasi yang ada, yakni kondisi pemelajar sebagai anak-anak dan adanya keterbatasan pemelajar dalam mengeksplorasi bahasa Indonesia sehingga memerlukan penjelasan konsep dan contoh terlebih dahulu sebagaimana yang menjadi ciri dari pendekatan deduktif. 


\section{KESIMPULAN}

Berdasarkan temuan dari studi pendahuluan dalam analisis kebutuhan dan situasi, dapat diketahui bahwa pengembangan materi yang paling mendesak dibutuhkan adalah materi ajar membaca untuk BIPA A1 berbasis pendekatan deduktif. Adapun penelitian ini merupakan tindak lanjut dari penelitian pendahuluan tersebut. Penelitian ini membahas penyusunan silabus dan materi ajar yang berbentuk buku teks dengan menggunakan pendekatan deduktif. Buku teks yang dikembangkan memuat (1) kaidah pada bagian awal, (2) diikuti contoh-contoh relevan, dan (3) latihan yang memadai. Nama lain dari pendekatan deduktif yaitu pendekatan tradisional yang pengajarannya berpola umum ke khusus dan berpusat pada guru. Pemilihan bentuk materi ajar berupa buku teks sesuai dengan konsep tersebut.

Pendekatan deduktif menjadi pendekatan paling relevan karena berkaitan dengan pengguna materi ajar yang merupakan siswa BIPA A1, yaitu siswa yang memiliki kemampuan bahasa Indonesia nol atau paling awal. Dalam kaitannya dengan penggunaan materi bagi siswa SD yang masih tergolong anak-anak, materi ajar yang dikembangkan juga harus memuat ilustrasi yang menarik. Pada anak-anak, proses belajar yang paling efektif yaitu dengan cara meniru sehingga penyajian materi ajar yang diperkaya konsep, contoh sebelum aktivitas latihan untuk siswa, dan ilustrasi menarik akan membantu siswa. Selain itu, siswa BIPA A1 belum dapat dilepas untuk belajar secara mandiri sehingga masih sangat membutuhkan peran pengajar baik untuk mencontohkan maupun untuk mendampingi.

Penelitian ini masih dalam tahap penyusunan produk pengembangan, sehingga penelitian ini masih perlu dilanjutkan dengan uji kelayakan sebagaimana tahapan penelitian pengembangan seharusnya. Setelah semua langkah-langkah penelitian pengembangan diakukan baru lengkaplah suatu penelitian pengembangan tersebut.

\section{UCAPAN TERIMA KASIH}

Peneliti menyampaikan ucapan terima kasih kepada Lembaga Pengelola Dana Pendidikan (LPDP) selaku pemberi sponsor sehingga penelitian ini dapat dilakukan dan akan terlaksana secara penuh. Ucapan terima kasih juga disampaikan kepada Universitas Negeri Jakarta sebagai lembaga legalisasi penelitian, Sekolah Dasar D'Royal Moroco Integrative Islamic School atas pemberian izin untuk dapat melakukan penelitian di sekolah tersebut, dan tim redaksi Jurnal Aksis atas saran dan masukan untuk perbaikan penulisan artikel ini.

\section{REFERENSI}

Agustina, R. \& Hariyadi. (2018). Penerapan Metode SQ3R dan Metode PQ3R terhadap Keterampilan Membaca pada Mahasiswa. Aksis: Jurnal Pendidikan Bahasa dan Sastra Indonesia. 2 (1), 69-80. doi: doi.org/10.21009/AKSIS.020105

Biduri, F.N., Rasyid, Y., \& Emzir. (2018). The analysis of needs on learning materials in context-based reading mandarin language and culture. Journal of Education, Teaching, and Learning, 3(1), 9-16. doi: http://dx.doi.org/10.26737/jetl.v1i1.454 
Borg, W.R., Gall, M.D., \& Gall, J.P. (2003). Educational Research: An Introduction ( $7^{\text {th }}$ Edition). Indiana: Pearson.

Brown, J.D. (1995). Elements of Language Curriculum: A Systematic Approach to Program Development. Boston: Heinle \& Heinle.

Brumfit, C.J. (1984). General English Syllabus Design. Oxford: Pergamon Press. Council of Europe. (2001). Common European Framework of Reference for Languages: Learning, Teaching, Assesment. Strasbourg: Cambridge University Press. Retrieved from www.coe.int/lang-CEFR

Hmedan, H.A.A., \& Nafi, J.S.I. (2016). The effect of using inductive and deductive methods on $7^{\text {th }}$ grade students' achievement in grammar in Bethlehem district and their attitudes toward EFL. International Journal of Education and Social Science, 3(9), 38-53.

Kementerian Pendidikan dan Kebudayaan. (2009). Undang-Undang Nomor 24 Tahun 2009. Retrieved from http://www.kemendagri.go.id/produkhukum/2009/07/09/undang-undang-no-24-tahun-2009

Kementerian Pendidikan dan Kebudayaan. (2014). Peraturan Kementerian Pendidikan dan Kebudayaan No. 31 Tahun 2014. Retrieved from http://kelembagaan.ristekdikti.go.id/wpcontent/uploads/2016/11/permen_tahun2014_nomor031-1.pdf.

Kementerian Pendidikan dan Kebudayaan. (2017). Peraturan Kementerian Pendidikan dan Kebudayaan No. 27 Tahun 2017. Retrieved from http://jdih.kemdikbud.go.id/new/public/produkhukum

Khusniyah, N.L., \& Lustyantie, N. (2017). Improving English reading comprehension ability through survey, questions, read, record, recite, review strategy (SQ4R). English Language Teaching, 10(12), 202-211. doi: 10.5539/elt.v10n12p202

Muliastuti, L. (2014). Materi ajar BIPA berbasis CEFR dan pendekatan integratif. In Pranowo, Setyaningsih, Y., \& Rahardi, R.K. (Eds.), Optimalisasi fungsi bahasa Indonesia sebagai wahana pembentukan mental dan karakter bangsa di era globalisasi menuju Indonesia emas 2045. Conference proceeding of Pertemuan Ilmiah Bahasa dan Sastra Indonesia (PIBSI) XXXVII, Yogyakarta, Indonesia. Retrieved from https://repository.usd.ac.id/3668/1/2077 _Artikel+PIBSI+XXXVII.pdf

Muliastuti, L. (2017). Bahasa Indonesia bagi Penutur Asing: Acuan Teori dan Pendekatan Pengajaran. Jakarta: Yayasan Pustaka Obor Indonesia.

Purwahida, R. (2017). Interaksi sosial pada kumpulan cerpen Potongan Cerita di Kartu Pos karangan Agus Noor dan implikasinya terhadap pembelajaran sastra di SMA. Aksis: Jurnal Pendidikan Bahasa dan Sastra Indonesia 1(1). 118-134. doi: doi.org/10.21009/AKSIS.010107 
Purwahida, R. (2018). Problematika Pengembangan Modul Pembelajaran Baca Tulis Anak Usia Sekolah Dasar. Aksis: Jurnal Pendidikan Bahasa dan Sastra Indonesia 2(1). 118-134. doi: doi.org/10.21009/AKSIS.020108

Riley, J. (2006). Language and Literacy 3-7: Creative Approach to Teaching. London: SAGE Publication

Rivai, O.S., et. al. (2010). Pemetaan Pengajaran Bahasa Indonesia bagi Penutur Asing (BIPA) di Asia. Retrieved from http://km.ristek.go.id/assets/files/125Pendidikan/BIPAdiAsia /BIPAdiAsia.pdf.

Sagala, S. (2008). Konsep dan Makna Pemelajaran. Bandung: Alfabeta.

Santosa, A. I., Rafli, Z., \& Lustyantie, N. 2018. Pengaruh pola asuh orang tua dan sikap bahasa terhadap kemampuan membaca pemahaman. Jurnal Pendidikan Bahasa dan Sastra, 18(1), 69-80. doi: http://dx.doi.org/10.17509/bs_jpbsp.v18i1.12147

Shaffer, C. (1989). A comparison of inductive and deductive approaches to teaching foreign languages. The Modern Language Journal, 73(4), 395-403. doi: https://doi.org/10.1111/j.1540-4781.1989.tb05319.x

Sudiana, I.N. (2007). Membaca. Malang: UM Press.

Suhartatik. (2018). Makna Leksikal Bahasa Madura Keadaan Alam Nelayan di Pesisir Kepulauan Sumenep. Aksis: Jurnal Pendidikan Bahasa dan Sastra Indonesia 2(1). 107-126. doi: doi.org/10.21009/AKSIS.020107

Tarigan, H.G. (1986). Teknik Pengajaran Keterampilan Berbahasa. Bandung: Angkasa.

Tomlinson, B. (2007). Developing Materials for Language Teaching. London: Continuum.

Wahyuni, S. (2013). Cepat Bisa Baca. Jakarta: Gramedia Pustaka Utama. 